\title{
Diagnosis and Root Canal Treatment in a Mandibular Premolar with Three Canals
}

\author{
Lanuce Rosa SOARES ${ }^{1}$ \\ Marcos ARRUDA ${ }^{1}$ \\ Marcos Pôrto de ARRUDA ${ }^{2,3}$ \\ Andréa Leão RANGEL ${ }^{1}$ \\ Edson TAKANO ${ }^{1}$ \\ Jacy Ribeiro de CARVALHO JÚNIOR ${ }^{1}$ \\ Paulo Cesar SAQUY ${ }^{4}$ \\ ${ }^{1}$ Dental School, Federal University of Goiás, Goiania, GO, Brazil \\ ${ }^{2}$ Dental School, Catholic University of Brasilia, Brasilia, DF, Brazil \\ ${ }^{3}$ Dental School, University of Ribeirão Preto, Ribeirão Preto, SP, Brazil \\ ${ }^{4}$ Ribeirão Preto Dental School, University of São Paulo, Ribeirão Preto, SP, Brazil
}

\begin{abstract}
This paper presents a case report of a left mandibular second premolar with three canals and three different apical foramina. A 39 -yearold male patient presented to our clinic with pain in the mandibular left second premolar. Initially, pain was caused by cold stimulus and later was spontaneously. The intraoral clinical examination revealed a fractured amalgam restoration with occlusal caries. Percussion and cold (Endo-Frost) tests were positive. The radiographic examination showed the presence of two roots. The probable diagnosis was an acute pulpitis. After access cavity, it was observed remaining roof of the pulp chamber and mild bleeding in the tooth lingual area, indicating the possible presence of a third canal. The endodontic treatment was completed in a single session using Root ZX apex locator and K3 NiTi rotary system with surgical diameter corresponding to a .02/45 file in the three canals and irrigation with $1 \%$ sodium hypochlorite. The canals were obtured with gutta-percha cones and Sealer 26 using the lateral condensation technique. After 1 year of follow-up, the tooth was asymptomatic and periapical repair was observed radiographically. Internal alterations should be considered during the endodontic treatment of mandibular second premolars. The correct diagnosis of these alterations by the analysis of preoperative radiographs can help the location of two or more canals, thereby avoiding root therapy failure.
\end{abstract}

Key Words: dental pulp cavity, dental pulp diseases, endodontic, root canal therapy.

\section{INTRODUCTION}

The anatomy of the rot canal system determines the parameters under which the endodontic treatment will be accomplished and directly affects the therapy success. Mandibular premolars have great variability on their internal morphology due to the possible presence of more than one root canal (1-6). Tzanetakis et al. (7) reported that the incidence of two or more canals in the mandibular second premolar can range from 1.2 to $34 \%$. The occurrence of three canals in mandibular second premolars has been reported as $0.0 \%(8)$ and $0.4 \%(9)$, and is characterized by the presence of a wide canal in the lingual face and two small canals in the buccal face (mesiobuccal and distobuccal).

There have been reports of mandibular second premolar with 3,4 and even 5 root canals $(5,10,11)$. These reports demonstrate that such anatomic variation might occur in clinical practice, in spite of its low incidence. Morphologic variations of the pulp cavity have been documented and diagnosed by computed tomography (12) and optical microscopy (13), but most variations in tooth anatomy can be identified radiographically.

This paper presents and discusses, by the analysis of radiographic images, the case of an endodontic treatment performed in a mandibular second premolar 
with three canals and three different apical foramina.

\section{CASE REPORT}

A 39-year-old male patient presented to our clinic with pain in the left mandibular second premolar. The intraoral clinical examination revealed a fractured amalgam restoration with occlusal caries in this tooth. The patient reported that the pain was initially caused by cold stimulus that ceased few minutes after its removal. After a short period, the pain ceased only with analgesics and afterwards, it became spontaneous, intense and pulsed.

The preoperative periapical radiograph showed the presence of two canals and two roots, one mesial and one distal (Fig 1A). The probable diagnosis was an acute pulpitis and the endodontic treatment was indicated. The patient received local anesthesia (3\% lidocaine with 1 : 100000 adrenaline) and a rubber dam was placed and disinfected with $1 \%$ sodium hypochlorite. The access cavity was prepared with round diamond burs (KG Sorensen, Barueri, SP, Brazil) mounted in a water-cooled high-speed handpiece. After reaching the pulp chamber, the roof was removed and the lateral walls were prepared with a safe-end tapered bur (Endo-Z; Dentsply/Maillefer, Ballaigues, Switzerland) positioned parallel to the long axis of the tooth. The divergence of the cavity walls was provided by the conicity of the Endo $\mathrm{Z}$ drill.

Mesial and distal canals were located with \#08 and \#10 K-files (Dentsply/Maillefer). During the standard canal preparation, it was noticed that the initial instruments crossed when placed into mesial and distal canals. Therefore, the access cavity was widened in the tooth lingual face, revealing residual pulp chamber roof and mild bleeding in this area, suggesting the presence of a lingual canal. Exploration confirmed the presence of three root canals: mesiobuccal, distobuccal and lingual.

The canals were irrigated with $1 \%$ sodium hypochlorite and the working length was determined using the Root ZX apex locator (J. Morita, Tokyo, Japan) (Fig.1B). Biomechanical preparation was accomplished with the K3 nickel-titanium rotary system (SybronEndo, Orange, CA, USA). The roots cervical third were prepared with $.06 / 30$ and $.06 / 25$ instruments followed by the apical preparation with $.04 / 20, .02 / 20$, $04 . / 25,02 / 25, .02 / 30, .02 / 35, .02 / 40$ and $.02 / 45$, being this last one the apical master file of the three canals.

The canals were irrigated with $1 \%$ sodium hypochlorite and were filled by lateral condensation of gutta- percha cones and Sealer26 endodontic sealer (Dentsply Ind. e Com. Ltda., Petrópolis, RJ, Brazil) (Fig 1 C-E).

\section{DISCUSSION}

Mandibular second premolar is one of the most difficult teeth for the endodontic treatment (14). This can be attributed to variations in the internal morphology of their pulp cavity, considering the number of root canals, apical deltas and lateral canals $(13,15)$. In addition, the access cavities in these teeth are relatively small, hence reducing the visualization of the area. A wider endodontic access is necessary to locate extra root canals (7).

Preoperative radiographs are used to identify anatomical alterations of the root canal system. The analysis of the anatomical aspects of pulp chamber roof can also help identifying these internal variations thus, facilitating the properly location of all root canals $(13,16)$.

During radiographic examination, a careful interpretation of the periodontal ligament space (Fig 1A) could suggest the presence of an extra root or canal. Indeed, in the present case, it can be noticed a sudden change of the radiopacity of the canal space (Fig 1A). The radiolucent space uniformly disappears from the pulp chamber, suggesting a possible presence of an additional canal $(10,13,17)$. In these cases, in order to better visualize the pulp chamber, the access cavity should have divergent walls to the oclusal face. In the present case, this procedure was done with the Endo Z drill (Dentsply/Maillefer) positioned parallel to the teeth long axis. The divergence of the cavity walls was provided by the conicity of the active part of the drill.

In the case reported in this paper, some opening resistance was felt during the initial negotiation of canals with \#08 and \#10 instruments, indicating the presence of more root canals. At this moment, it is important to use tactile sensibility and also observe the direction of the endodontic instrument during its introduction into the canal. After localization of the canals, the cervical third was widened with the \#25.10 Ni-Ti instrument of K3 system (SybronEndo). Preflaring of the root cervical portion allows a correct determination of the initial instrument and, consequently, a better cleaning of the apical third and filling of the root canals (18-20).

Although in vitro and in vivo studies $(5,10,11)$ report low incidence of mandibular second premolar with three canals, each case should be analyzed individu- 
ally by a careful radiographic and clinical examination,
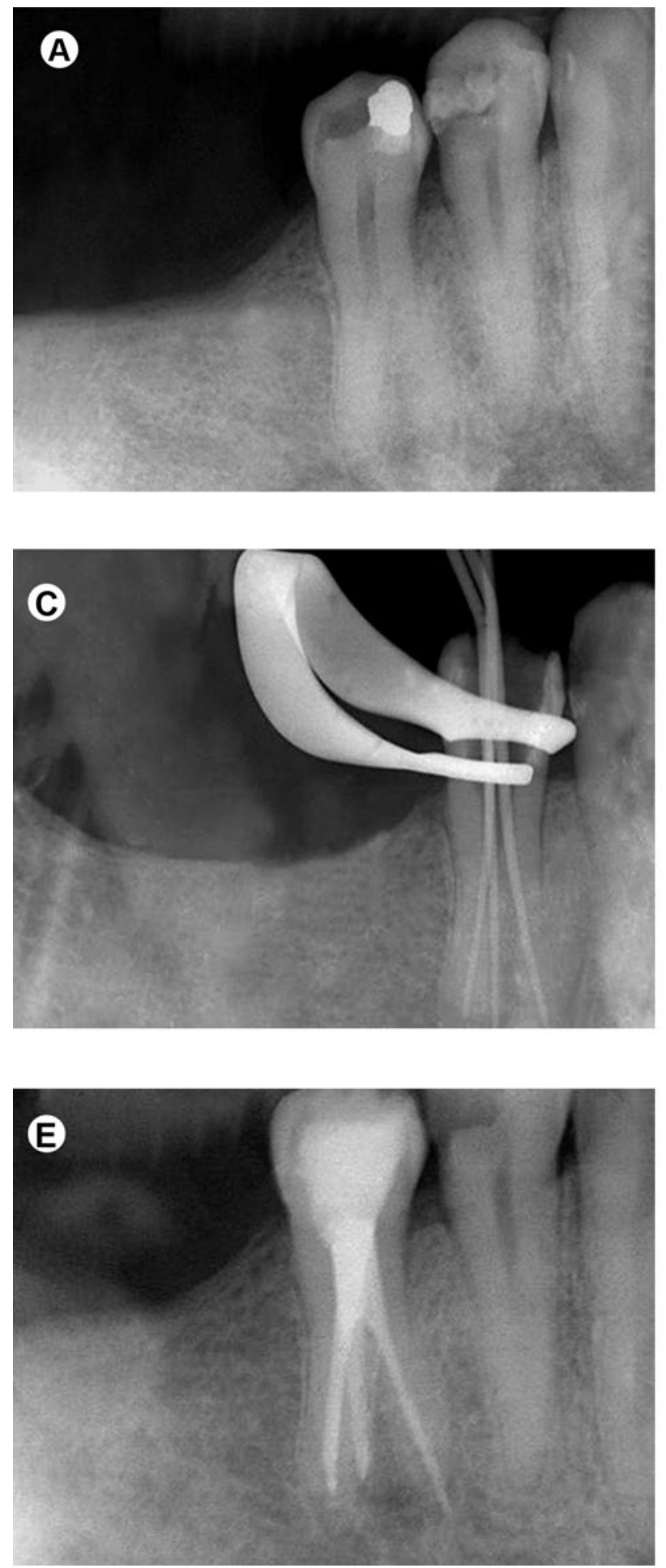

Fig. 1. Panel of periapical radiographs documenting teh case. $\mathrm{A}=$ Preoperative radiograph; $\mathrm{B}=$ Working length determination; $\mathrm{C}=$ Selection of the main gutta-percha cones; $\mathrm{D}=$ Testing of the canal filling; $\mathrm{E}=$ Final obturation; $\mathrm{F}=1$-year follow-up. 


\section{RESUMO}

O presente artigo teve como objetivo a apresentação de um caso clínico de um segundo pré-molar inferior esquerdo com três canais com três forames distintos. Paciente de 39 anos de idade, leucoderma, relatava dor inicialmente estimulada ao frio e posteriormente dor espontânea no referido dente. No exame intraoral foi constatada restauração de amálgama fraturada e cárie oclusal. Os testes de sensibilidade à percussão e ao frio (Endo-Frost) foram positivos. O exame radiográfico evidenciou a presença de duas raízes. O diagnóstico provável foi de pulpite aguda. Após o preparo de acesso à câmara pulpar notou-se a presença de teto remanescente e um leve sangramento, sendo possível localizar um terceiro canal na região lingual. O tratamento endodôntico foi realizado em uma única sessão, com auxílio do localizador apical Root ZX, e o preparo biomecânico com sistema rotatório com limas de NiTi K3 com diâmetro cirúrgico correspondente ao instrumento $.02 / 45$ nos três canais, e a solução química auxiliar hipoclorito de sódio $1 \%$. A obturação foi realizada por condensação lateral de guta-percha e cimento Sealer26. Durante o período de proservação de 1 ano, o dente apresentou-se clinicamente assintomático com reparação dos tecidos periapicais observada radiograficamente. Alterações internas devem ser consideradas durante tratamento endodôntico em segundos pré-molares inferiores. O correto diagnóstico destas alterações por meio da análise de radiografias pré-operatórias podem auxiliar na localização de dois ou mais canais, evitando dessa maneira o insucesso do tratamento a ser realizado.

\section{ACKNOWLEDGEMENTS}

The authors are grateful to the Professors Edson Takano and Jacy Ribeiro de Carvalho Júnior from the Endodontics Specialization Course of the Federal University of Goiás for their support.

\section{REFERENCES}

1. Barrett MT. The internal anatomy of teeth with special reference to the pulp and its branches. Dental Cosmos 1925;67:581-592.

2. Amos ER. Incidence of bifurcated root canals in mandibular bicuspids. J Am Dent Assoc 1955;50:70-71.

3. England MC Jr, Hartwell GR, Lance JR. Detection and treatment of multiple canals in mandibular premolars. J Endod 1991;17:174178.
4. Baisden MF, Kulild JC, Weller RN. Root canal configuration of the mandibular first premolar. J Endod 1992;18:505-508.

5. Macri E, Zmener O. Five canals in a mandibular second premolar. J Endod 2000;26:304-305.

6. Almeida-Gomes F, Sousa BC, Santos RA. Unusual anatomy of mandibular premolars. Aust Endod J 2006;32:43-45.

7. Tzanetakis GN, Lagoudakos TA, Kontakiotis EG. Endodontic treatment of a mandibular second premolar with four canals using operating microscope. J Endod. 2007;33:318-321.

8. Vertucci FJ. Root canal anatomy of the human permanent teeth. Oral Surgery 1984;58:589-599.

9. Zillich R, Dowson J. Root canal morphology of mandibular first and second premolars. Oral Surg Oral Med Oral Pathol 1973;36:738-744.

10. Cleghorn BM, Christie WH, Dong CC. Anomalous mandibular premolars: a mandibular first premolar with three roots and a mandibular second premolar with a C-shaped canal system. Int Endod J 2008;41:1005-1014.

11. Al-Fouzan KS. The microscopic diagnosis and treatment of a mandibular second premolar with four canals. Int Endod $\mathrm{J}$ 2001;34:406-410.

12. Cleghorn BM, Christie WH, Dong CC. The root and root canal morphology of the human mandibular first premolar: a literature review. J Endod 2007;33:509-516.

13. De Moor RJG, Calberson FLG. Root canal treatment in a mandibular second premolar with three root canals. J Endod 2005;31:310313.

14. Awawdeh LA, Al-Qudah AA. Root form and canal morphology of mandibular premolars in a Jordanian population. Int Endod J 2008;41:240-248.

15. Nallapati S. Three Canal Mandibular First and Second Premolars: A Treatment Approach. A Case Report. J Endod 2005;31:474-476.

16. Cleghorn BM, Christie WH, Dong CC. The root and root canal morphology of the human mandibular second premolar: a literature review. J Endod 2007;33:1031-1037.

17. Vertucci FJ. Root canal morphology of mandibular premolars. J Am Dent Assoc 1978;97: 47-50.

18. Wu MK, Barkis D, Roris A, Wesselink PR. Does the first file to bind correspond to the diameter of the canal in the apical region? Int Endod J 2002;35:264-267.

19. Vanni JR, Santos R, Limongi O, Guerisoli DM, Capelli A, Pecora JD. Influence of cervical preflaring on determination of apical file size in maxillary molars: SEM analysis. Braz Dent J 2005; 16:181186.

20. Khademi A, Yazdizadeh M, Feizianfard M. Determination of the minimum instrumentation size for penetration of irrigants to the apical third of root canal systems. J Endod 2006;32:417-420. 